
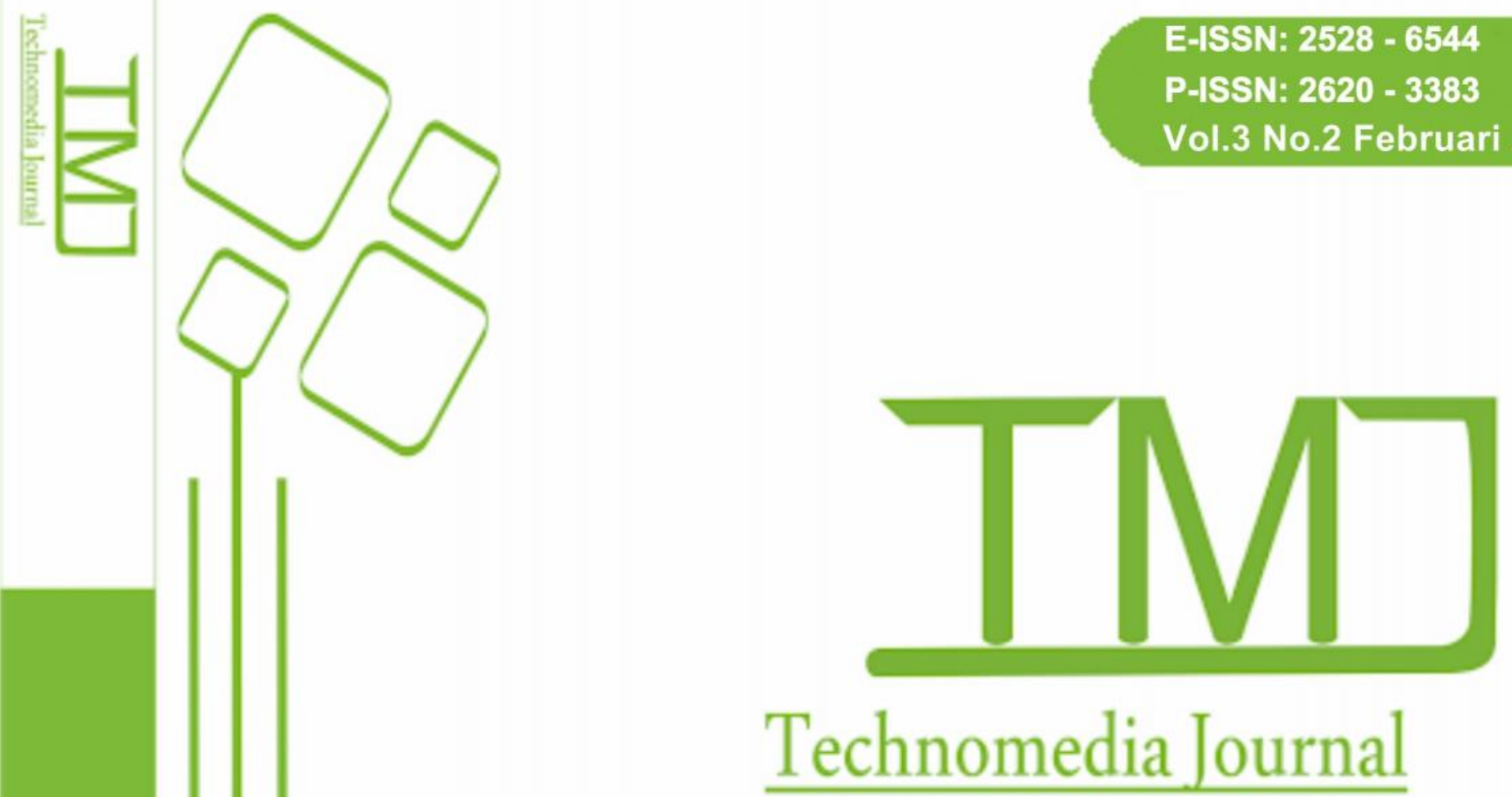

Technomedia Journal

iLearning Journal Center (iJC)

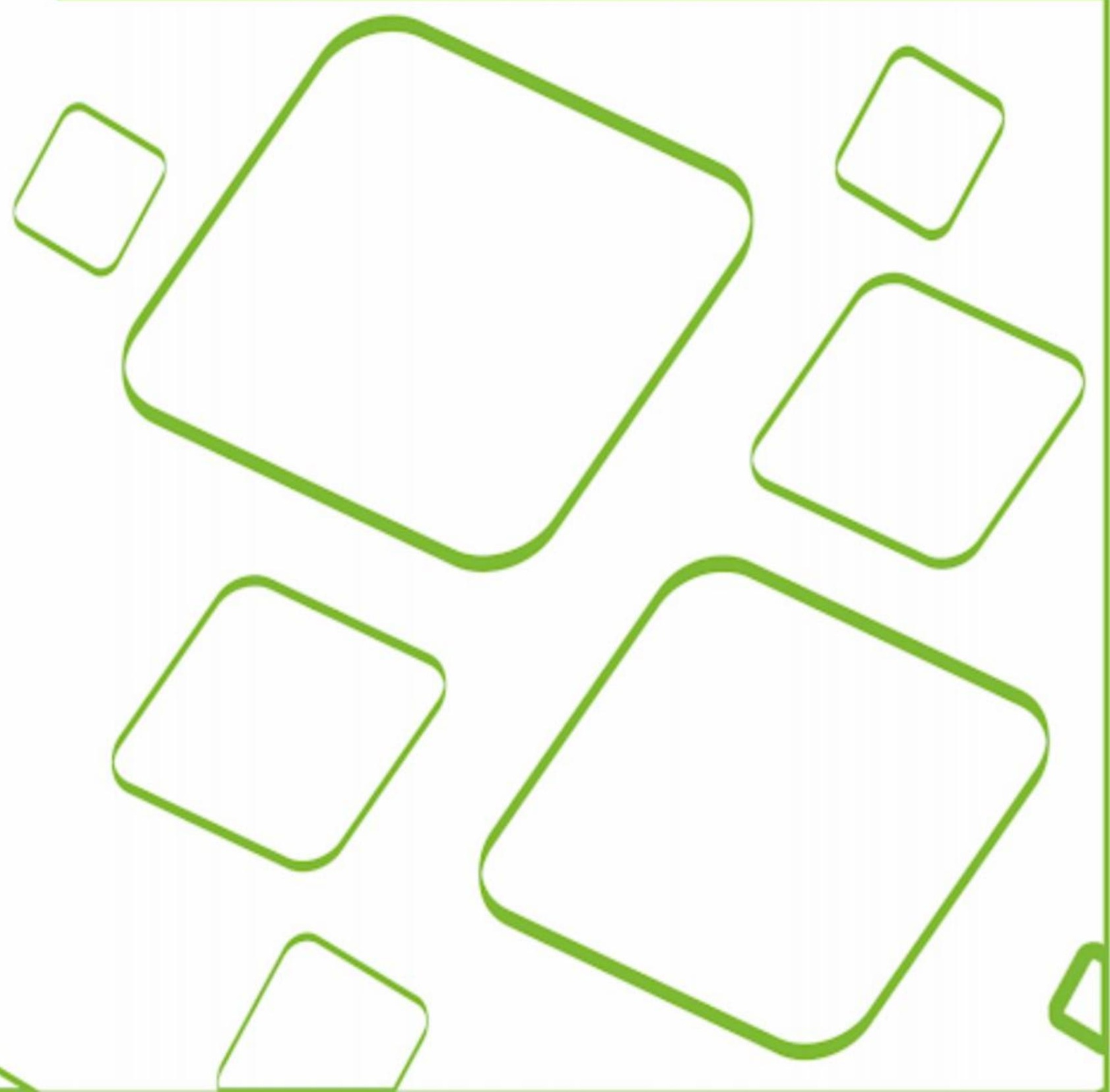




\title{
Penerapan Viewboard Informatif Pada Asosiasi Perguruan Tinggi Swasta Indonesia Dalam Era Industri 4.0
}

\author{
Untung Rahardja ${ }^{1}$ \\ Ninda Lutfiani ${ }^{2}$ \\ Aulia Yolandari ${ }^{3}$ \\ Jurusan Sistem Informasi, STMIK Raharja, Tangerang \\ e-mail: untung@raharja.infor ${ }^{1}$,ninda@raharja.info ${ }^{2}$, aulia.yolandari@raharja.info ${ }^{3}$
}

\begin{abstract}
ABSTRAK
Perkembangan teknologi saat ini dihadapi oleh tantangan untuk memenuhi permintaan dunia yang terus meningkat untuk barang modal dan barang konsumsi secara bersamaan memastikan evolusi berkelanjutan dari eksistensi manusia dalam dimensi sosial, lingkungan dan ekonominya. Penciptaan nilai industri di awal negara-negara industri dibentuk oleh perkembangan menuju tahap keempat industrialisasi, yang disebut Industri 4.0. Saat ini, penyebaran informasi mengenai pendidikan dan media komunikasi seperti website APTISI dilakukan secara up to date dan terangkum dalam viewboard. pemecahan masalah pada sistem ini adalah sistem informasi yang berbasis viewboard pada sebuah official site yang digunakan sebagai tempat ataupun wadah dan penyebaran informasi yang dikhususkan bagi para anggotanya serta dapat menampilkan kegiatan dimiliki oleh organisasi maupun institusi. Untuk mengatasi tantangan ini maka metode pendidikan juga harus diikuti dengan perkembangan teknologi. Di dalam penelitian ini menggunakan dua metode yaitu metode Use Case dan Analisa SWOT. Dengan adanya penelitian ini, diharapkan mampu menghimpun kegiatan asosiasi dan dapat memberikan hasil yang lebih baik dalam penyampaian informasi artikel dalan official site.
\end{abstract}

Kata Kunci : Industri 4.0, Viewboard, Official Site.

\section{ABSTRACT}

Current technological developments are faced with the challenge of meeting the increasing world demand for capital goods and consumer goods simultaneously ensuring the continued evolution of human existence in its social, environmental and economic dimensions. The creation of industrial value at the beginning of industrial countries was formed by developments towards the fourth stage of industrialization, called Industry 4.0. At present, the dissemination of information about education and communication media such as the APTISI Website is carried out up to date and summarized in the viewboard. problem solving in this system is a viewboard-based information system on an official site that is used as a place or container and the dissemination of information specifically for its members and can display 
activities owned by organizations and institutions. To overcome this challenge the education method must also be followed by technological developments. In this study using two methods, namely the Use Case method and SWOT Analysis. With this research, it is expected to be able to gather association activities and can provide better results in the delivery of article information in the official site.

Keywords: Industry 4.0, Viewboard, Official Site.

\section{PENDAHULUAN}

Manufaktur yang terhubung secara digital, seringkali disebut sebagai "Industry 4.0" yang pada saat ini sangat mempengaruhi perkembangan teknologi dunia yang mengalami perkembangan pesat dan sangat mempengaruhi dunia bisnis[1].

Dalam lingkungan bisnis yang kompetitif saat ini, salah satunya perguruan tinggi menghadapi tantangan dalam menangani masalah data yang sangat cepat pengambilan keputusan untuk meningkatkan produktivitas[2] [3]. Banyak Sistem manufaktur belum siap untuk mengelola data yang besar dengan kurangnya alat analisis cerdas[5]. Jerman memimpin a transformasi menuju Revolusi Industri Generasi ke-4 (Industri 4.0) manufaktur dan inovasi layanan[6] [7] [8].

Industri 4.0 mendefinisikan sistem proses produksi tergantung pada perangkat yang berkomunikasi secara otonom dengan satu sama lain dan teknologi ini menjadi rantai nilai dan masa depan yang dapat membuat keputusan terdesentralisasi berdasarkan mekanisme self organization dengan adanya salinan virtual dunia fisik sistem memonitor ini juga disebut revolusi industri keempat[9] [10].

Website asosiasi sangat memberikan banyak manfaat bagi perusahaan maupun organisasi dalam penyebaran informasi. Pada website asosiasi ini juga tentunya memberikan informasi mengenai Perusahaan tersebut. Salah satu bagian paling penting dari website asosiasi adalah adanya sebuah berita atau artikel[11]. Penyebaran dan penyampaian informasi berupa berita ini tergolong kurang informatif bagi asosiasi dan sebagai besar perusahaan kurang mengetahui informasi persoalan asosiasi yang sifatnya non-akademik[12].

Penyebaran informasi yang cepat serta tepat sangat dibutuhkan masyarakat dalam melakukan aktivitas kehidupan[13]. Cara penyampaian informasi yang dilakukan dari Zaman dahulu tidak berubah dan selalu berkembang menciptakan pengaruh besar kepada para penerima informasi[14]. 


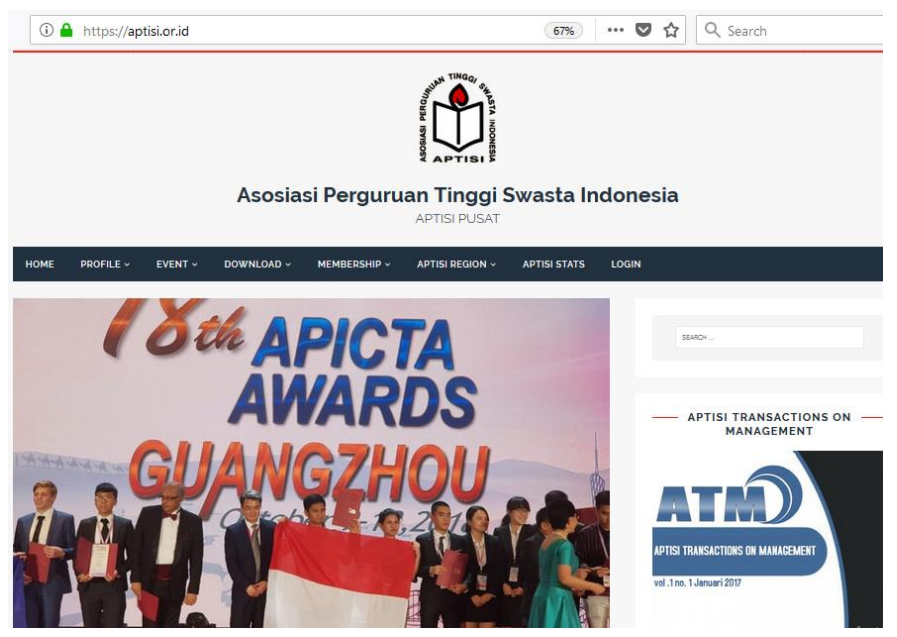

Gambar 1. Website APTISI (aptisi.or.id)

Sumber: http://aptisi.or.id/, 2018

Gambar 1. diatas ialah tampilan awal yang tertera pada website aptisi.or.id. Dimana pada website tersebut langsung mengarah kepada halaman utama yaitu Berita terupdate dan informatif[15].

Berita merupakan laporan peristiwa terbaru. Tidak semua peristiwa layak dilaporkan hanyalah peristiwa yang memenuhi kriteria yaitu yang mengandung nilai berita [17]. Sedangkan berita, menurut Doug Newson dan James A. Wollert (Sumadiria, 2005: 64) berita adalah apa saja yang ingin dan perlu diketahui orang atau lebih luas lagi oleh masyarakat. Namun pada website aptisi.or.id tidak hanya berita saja tetapi menyajikan informasi Seminar, Undangan, Event dan juga kegiatan yang berhubungan dengan asosiasi di pusat maupun daerah yang tergabung dalam APTISI[18].

\section{METODE PENELITIAN}

\subsection{Analisa SWOT}

Dalam penelitian ini, menggunakan desain penilaian deskriptif analitis yaitu dengan cara mendeskripsikan melalui analisis dari yang didapatkan. Deskriptif analitis merupakan metode yang tidak menjabarkan analisis nya saja tetapi juga mengamati, menganalisis dari data yang didapatkan[19].

Metode analisa sistem yang digunakan berupa analisa SWOT. SWOT adalah sebuah metode analisis kondisi yang menjelaskan kondisi objek dalam 4 (empat) kategori Strength (Kekuatan), Weakness (Kelemahan), Opportunity (Faktor pendukung) dan Threat (Ancaman) terhadap sistem official site APTISI ini sehingga dapat menganalisa apapun yang mencakup ke dalam SWOT.

Sedangkan menurut Wanti (2014) analisa SWOT merupakan strategi perencanaan yang penting untuk membandingkan faktor internal, yaitu : kekuatan dan kelemahan serta eksternal, yaitu peluang dan ancaman. 


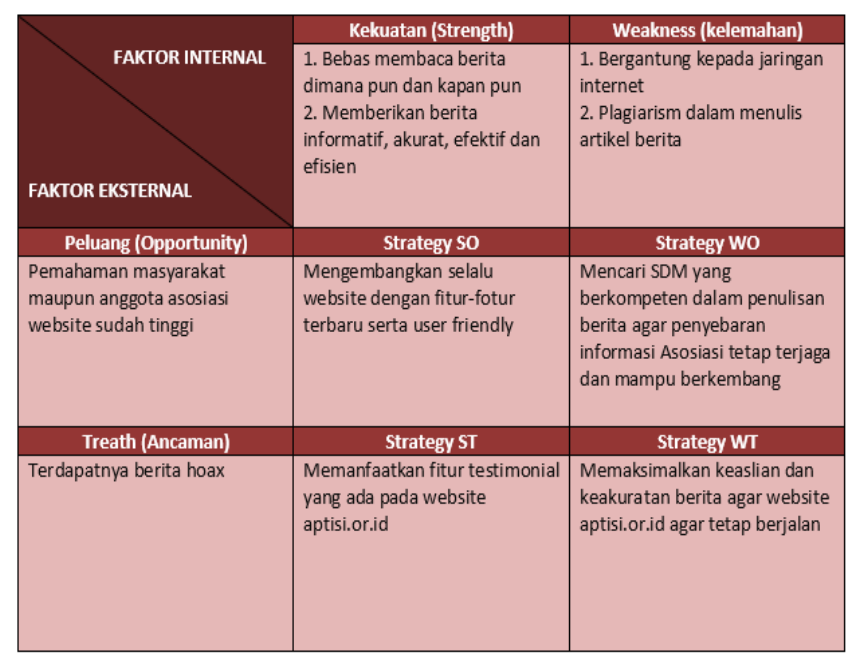

Gambar 2. Analisa SWOT Website aptisi.or.id

Pada gambar 2. adanya analisa SWOT dimana hal ini di dasari dari faktor internal dan eksternal yang meliputi Kelemahan (Weakness), Peluang (Opportunity), Kekuatan (Strength) dan Ancaman (Threast). Dapat disimpulkan bahwa adanya rumusan Strategi SO berdasarkan perbandingan antara Kekuatan (Strength) dengan Peluang (Opportunity) merupakan Mengembangkan selalu website dengan fitur-fitur terbaru serta user friendly. Strategy WO dapat diterapkan berdasarkan perbandingan antara kelemahan (weakness) dan peluang (opportunity) merupakan Mencari SDM yang berkompeten dalan penulisan berita agar penyebaran informasi asosiasi tetap terjaga dan mampu berkembang. Strategi WT Kelemahan (Weakness) dan Ancaman (Threat) yang merupakan Memanfaatkan fitur testimonial yang ada pada website aptisi.or.id. Strategi ST diterapkan dalam perbandingan antara kekuatan (strength\} dan ancaman (thread) ialah Memaksimalkan keaslian dan keakuratan berita agar website aptisi tetap berjalan.

\subsection{Use case Diagram}

Menurut Wijayanto, 2013:33 use case diagram dibuat berdasarkan use case diagram dan activity diagram yang telah dibuat, maka dapat diperoleh yang digunakan dalam sistem. Serta Menurut Murad, 2013:57 Diagram Use Case adalah diagram yang bersifat status yang memperlihatkan himpunan use case dan aktor-aktor (suatu jenis khusus dari kelas). Diagram ini memiliki 2 fungsi, yaitu mendefinisikan fitur apa yang harus disediakan oleh sistem dan menyatakan sifat sistem dari sudut pandang user 


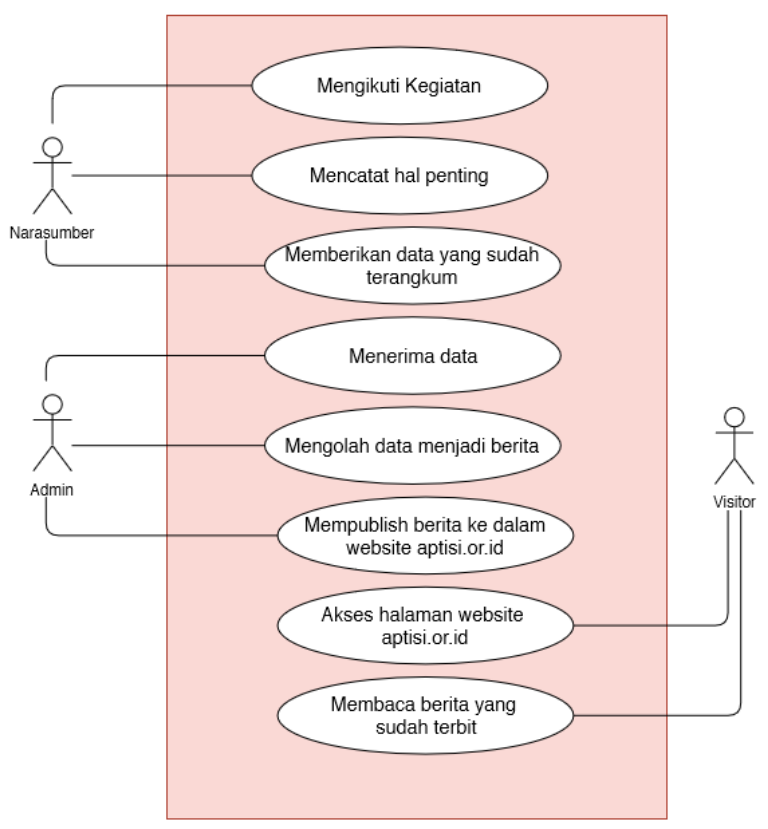

Gambar 3. Use case diagram

Berdasarkan gambar 3. Use Case Diagram yang di atas, maka dapat dijabarkan sebagai berikut:

a. 3 (tiga) Actor, yaitu Narasumber, Admin, dan Visitor.

b. 9 (sembilan) Use Case, yaitu Mengikuti Kegiatan, Mencatat Hal Penting, Memberikan Data yang Sudah Terangkum, Menerima Data, Menerima Data, Mengolah Data Menjadi Berita, Mempublikasikan Berita yang Sudah Dipublikasikan, Akses Halaman Utama Website, Baca Berita Yang Sudah Terbit.

\section{Hasil dan Pembahasan}

\subsection{Analisa Permasalahan}




\section{- ABOUT OFFICIAL SITE APTISI -}

Official Site APTISI Pusat merupakan website utama dari Asosiasi Perguruan Tinggi Swasta Indonesia. Tidak berbeda dengan official site lainnya untuk menyajikan informasi berupa sebuah berita maupun artikel, official site APTISI Pusat memiliki sebuah artikel. dan saat ini sudah tercatat bahwa terdapat 206 postingan dengan total view mencapai 107654 views dalam official site APTISI Pusat. User yang sering aktif posting berita yaitu Resti Rahmawati dengan total posting sebanyak 117 Post. Terbukti pula bahwa official site APTISI sudah dikenal oleh seluruh anggota, mahasiswa maupun masyarakat luas. Mengapa tidak. subscriber official site APTISI saat ini tercatat sebanyak 282 subscriber. Dalam official site ini tidak hanya untuk melihat berita atau artikel tetapi bisa berkomunkasi dengan sesama pengguna lain dan terbukti dengan adanya 307 comment. Mari kita tingkatkan kualitas official site APTISI Pusat dengan menjadi subscriber dan memberikan feedback berupa comment pada setiap artikel yang ada

Gambar 4. Tampilan About Official Site APTISI https://aptisi.or.id/

Perkembangan teknologi saat ini semakin hari semakin canggih dengan dimudahkan nya untuk mendapatkan sebuah informasi dari berbagai sumber dari media online. Asosiasi Perguruan Tinggi Swasta Indonesia (APTISI) memfasilitasi informasi organisasi, berita pendidikan, workshop, seminar dan lainnya[20]. Namun, dalam penyampaian informasi saat ini dirasa masih kurang maksimal dalam mengelola berita yang diolah dan informasi yang didapat dari narasumber.

Dengan adanya Official Site Asosiasi diharapkan dapat mempermudah organisasi maupun anggota APTISI untuk mendapatkan sebuah informasi berupa viewboard seputar Kegiatan Asosiasi. Dengan menampilkan informasi yang mudah serta efisien dan juga mampu diakses dimana saja dan kapan saja[21]. 


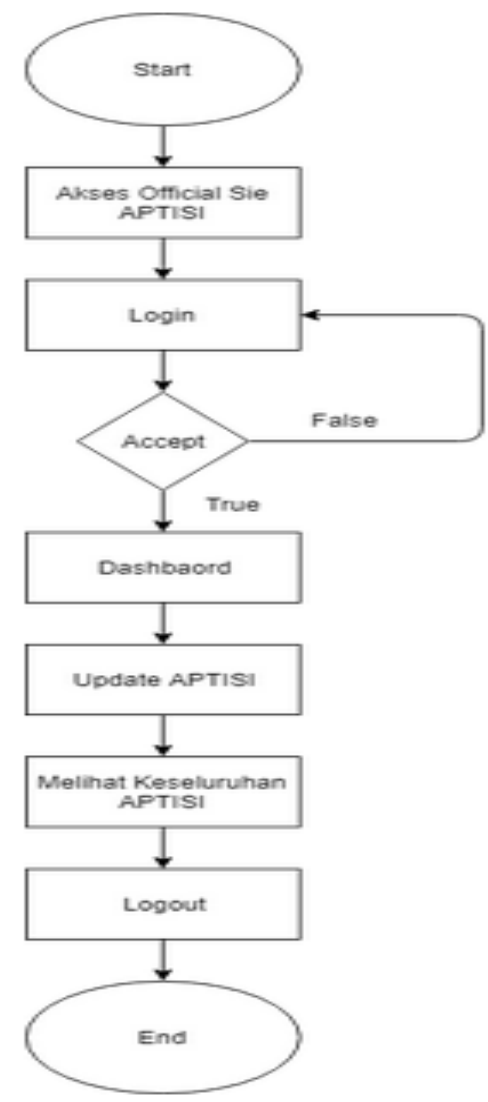

Gambar 5. Flowchart sistem yang berjalan

Gambar 5 merupakan penjelasan mengenai alur proses dalam penyampaian informasi yang berjalan[22], dalam proses yang dilakukan menggunakan akses official site APTISI untuk mengupdate sebuah berita pada tampilan website.

\subsection{Pemecahan Masalah}

Dengan adanya permasalahan yang dihadapi, maka diberikannya alternatif pemecahan masalah pada Official Site Asosiasi yaitu dengan secara rutin untuk membuat sebuah artikel maupun postingan yang berkaitan dengan kegiatan organisasi APTISI dan menampilkan viewboard guna menunjang informasi yang berkaitan kegiatan Asosiasi Perguruan Tinggi Swasta Indonesia[23].

\subsubsection{Listing Program}

$<$ div id="main-content" class="mh-content" > <article id="page-2225" class="mh-content-wrapper post-2225 page type-page status-publish hentry">

$<$ header class="entry-header" >

$<$ h1 class="entry-title page-title" $>$ Most Viewed Article $</$ h1 $>$ $</$ header $>$ 
$<$ div class="entry-content clearfix" $>$

$<$ p style="text-align: right;" $><$ span style="color: \#0000ff;" $><\mathrm{a}$ style="color: \#0000ff;" href="https://aptisi.or.id/all-post-with-the-mostviewed-articles/" target="_blank" rel="noopener" $\rangle\langle$ span style="textdecoration: underline;" $>$ View All $</$ span $></$ a $~></$ span $></$ p $>$ $<$ p style="text-align: center;" $><$ !DOCTYPE HTML $>$ $<\mathrm{html}>$

$<$ head $>$

$<$ meta http-equiv="Content-Type" content="text/html; charset=utf$8 ">$

$<$ title $>$ Dashboard $</$ title $>$

<script type="text/javascript"

src="https://ajax.googleapis.com/ajax/libs/jquery/1.8.2/jquery.min.js" $></ s c$ ript>

<style type="text/css">

$\$\{$ demo.css $\}$

$</$ style $>$

$</$ head $>$

$<$ body $>$

<script src="https://code.highcharts.com/highcharts.js" $></$ script $>$

<script src="https://code.highcharts.com/highcharts-3d.js" $\rangle\langle/$ script $\rangle$

<script src="https://code.highcharts.com/modules/exporting.js" $></$ script $>$

\#containermonth, \#slidermonth \{

min-width: 310px;

max-width: 800px;

margin: 0 auto;

\}

\#containermonth \{

height: 400px;

\}

$</$ style $>$

$\langle$ div id="containermonth" $></$ div $>$

Gambar 6. Script Tampilan Viewboard Postingan Artikel

Gambar 6 merupakan Script untuk menampilkan Postingan Artikel dengan views terbanyak, 
dimana script tersebut akan menampilkan 10 Artikel yang berisi views terbanyak, Jumlah pengunjung dalam artikel tersebut[24].

\section{Most Viewed Article}

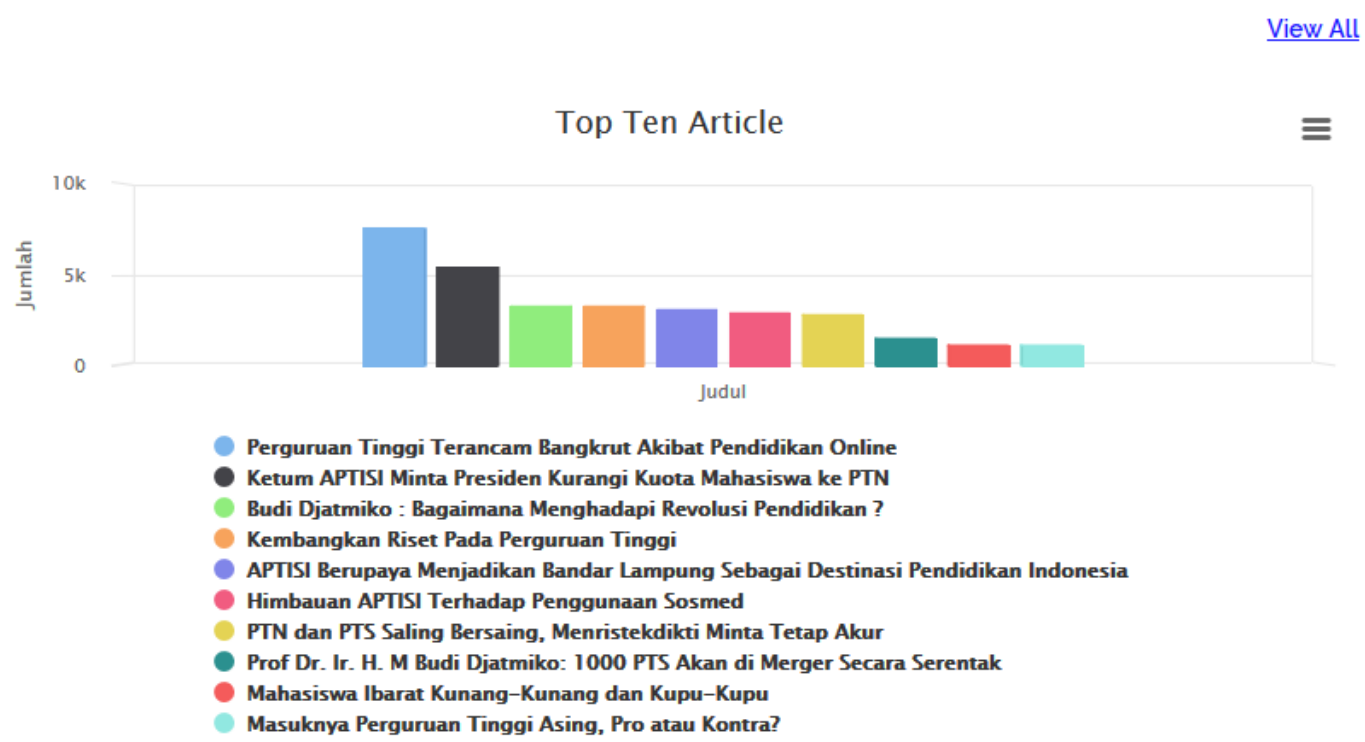

Gambar 7. Tampilan Viewboard Postingan Artikel

Gambar 7 merupakan tampilan viewboard postingan terbanyak yang terdapat 10 artikel kegiatan yang ditampilkan secara rinci mulai dari nama artikel kegiatan, Grafik berwarna yang membuat pengunjung ingin melihat ke 10 Artikel tersebut, dan memiliki informasi jumlah pengunjung di setiap postingannya[25].

\section{Kesimpulan}

Dalam penelitian mengenai viewboard informatif pada Artikel Kegiatan ini terdapat 2 (dua) permasalahan dengan diselesaikan menggunakan 3 (tiga) tahap, dan menghasilkan 2 (dua) kesimpulan yaitu:

A. Dengan adanya Official site viewboard yang mendasari adanya industri 4.0 ini terbukti memberikan hasil yang lebih baik lagi dalam memberikan informasi mengenai Artikel Kegiatan Asosiasi Perguruan Tinggi Swasta Indonesia (APTISI) dengan tampilan lebih menarik dan rapi dan juga Viewboard tersebut dapat dilihat oleh Masyarakat luas.

B. Dengan adanya Official site APTISI menjadikan wadah asosiasi untuk menghimpun kegiatan Anggota dan mendapatkan informasi Perguruan Tinggi Swasta di Indonesia.

\section{Saran}

Saran yang diberikan penulis untuk meningkatkan sistem Viewboard informatif APTISI selanjutnya yaitu dapat mengembangkan serta mengelola Official site APTISI sehingga penyebaran informasi dan seluruh potensi asosiasi terjaga dengan baik. 


\section{UCAPAN TERIMA KASIH}

Penulis mengucapkan terima kasih kepada Perguruan Tinggi Raharja yang telah memberi dukungan moral dan fasilitas terhadap penelitian ini.

\section{REFERENCES}

[1] Lee, J., Kao, H. A., \& Yang, S. (2014). Service innovation and smart analytics for industry 4.0 and big data environment. Procedia Cirp, 16, 3-8.

[2] Sanders, A., Elangeswaran, C., \& Wulfsberg, J. (2016). Industry 4.0 implies lean manufacturing: Research activities in industry 4.0 function as enablers for lean manufacturing. Journal of Industrial Engineering and Management, 9(3), 811-833.

[3] Kolberg, D., \& Zühlke, D. (2015). Lean automation enabled by industry 4.0 technologies. IFAC-PapersOnLine, 48(3), 1870-1875.

[4] Stock, T., \& Seliger, G. (2016). Opportunitiestata of sustainable manufacturing in industry 4.0. Procedia Cirp, 40, 536-541.

[5] A. Moeini, A. Marzoughi, H. Iman-Eini, S. Farhangi, "A modified control strategy for cascaded H-bridge rectifiers based on the low frequency SHE-PWM", Environment and Electrical Engineering (EEEIC), 2013 12th International Conference on , vol., no., pp.501,506, 5-8 May 2013.

[6] Almada-Lobo, F. (2016). The Industry 4.0 revolution and the future of manufacturing execution systems (MES). Journal of Innovation Management, 3(4), 16-21.

[7] Brettel, M., Friederichsen, N., Keller, M., \& Rosenberg, M. (2014). How virtualization, decentralization and network building change the manufacturing landscape: An Industry 4.0 Perspective. International Journal of Mechanical, Industrial Science and Engineering, 8(1), 37-44.

[8] Juditha, C. (2013). Akurasi Berita dalam Jurnalisme Online (Kasus Dugaan Korupsi Mahkamah Konstitusi di Portal Berita Detiknews). Pekommas, 16(3).

[9] J, Cowls and J, Bright. 2017. International Hyperlinks In Online News Media.

[10] Rahardja, U., Harahap, E. P., \& Suciani, A. (2017). Media Viewboard Sebagai Klasifikasi Jumlah Surat Keputusan Online Pada Perguruan Tinggi. Technomedia Journal, 2(1), 67-79.

[11] Rahardja, U., Lutfiani, N., \& Rahmawati, R. (2018). Persepsi Mahasiswa Terhadap Berita Pada Website APTISI. SISFOTENIKA, 8(2), 117-127.

[12] Rahardja, U., Lutfiani, N., \& Alpansuri, M. S. (2018). Pemanfaatan Google Formulir Sebagai Sistem Pendaftaran Anggota Pada Website Aptisi. or. id. SISFOTENIKA, 8(2), 128-139.

[13] Rahardja, U., Yusup, M., \& Aini, Q. (2014). Aplikasi Campus Learning System iOU (integrated Online Ujian) Dalam Mendukung Kegiatan iLearning Education (iDu) Pada Perguruan Tinggi. CCIT Journal, 7(3), 368-383. 
[14] Rahardja, U., Aini, Q., \& Khoirunisa, A. (2017). Implementasi Business Intelligence Menggunakan Highchart pada Sistem Penilaian Absensi berbasis YII Framework. CSRID (Computer Science Research and Its Development Journal), 9(2), 115-124.

[15] Rahardja, U., Harahap, E. P., \& Pratiwi, D. I. (2018). Pemanfaatan RinfoSheet Sebagai Media Informasi Laporan Penjualan Barang pada Raharja Internet Cafe. Jurnal Ilmiah Teknologi Informasi Asia, 12(1), 65-74.

[16] Rahardja, U., Harahap, E. P., \& Anjani, D. (2018). Pemanfaatan Rinfogroup Sebagai Media Diskusi Dan Penilaian Keaktifan Mahasiswa. Sisfotenika, 8(1), 81-92.

[17] Juliany, I. K., Salamuddin, M., \& Dewi, Y. K. (2018). PERANCANGAN SISTEM INFORMASI E-MARKETPLACE BANK SAMPAH BERBASIS WEB. SEMNASTEKNOMEDIA ONLINE, 6(1), 2-10.

[18] Handayani, I., Febriyanto, E., \& Bachri, E. W. (2018). Aplikasi Stat Counter Sebagai Alat Monitoring Aktivitas Website PESSTA+ Pada Perguruan Tinggi. SISFOTENIKA, 8(2), 188-197.

[19] Sunarya, P. A., Budiarto, E., \& Lestari, F. H. N. (2018). Improved Management Understanding of Research Through Concepts and Preliminary Studies for Empirical Problem Solving. Aptisi Transactions on Management (ATM), 2(2), 89-96.

[20] Febriyanto, E., Yulianto, F. H. N. L., \& LESTARI, F. H. N. (2018). Penerapan Viewboard Rooster Berbasis Bootstrap Sebagai Penunjang Pelayanan iDuhelp! Pada Perguruan Tinggi. Jurnal Ilmiah Teknologi Informasi Asia, 12(2).

[21] Handayani, I., Kurniati, D., \& Yakin, S. A. (2018). Penerapan Dashboard Sebagai Media Pengumpulan Data Laporan Penulisan Mahasiswa di Widuri Menggunakan Rinfo Spreadsheet Pada Perguruan Tinggi. Technomedia Journal, 2(2), 107-118.

[22] Rahardja, U., Handayani, I., \& Wijaya, R. (2018). Penerapan Viewboard Technomedia Journal menggunakan sistem iLearning Journal Center pada Perguruan Tinggi. Technomedia Journal, 2(2), 78-89.

[23] Alwiyah, A., Louangdy, T. T., \& Yolandari, A. (2018). Relation of Relationship Between Research Theory and Variable with Management Case Study. Aptisi Transactions on Management (ATM), 2(1), 70-78.

[24] Harjanto, R., Manurung, E. B. P., \& Lestari, A. D. (2018). Optimization of Proposal Management Arrangements as Learning Tools in Scientific Research Activities. Aptisi Transactions on Management (ATM), 2(1), 55-62.

[25] Zarlis, M., Astuti, S., \& Salamuddin, M. (2018). Analysis of Reading, Reference and Information Management on the Quality of Scientific Writing. Aptisi Transactions on Management (ATM), 2(1), 63-69. 